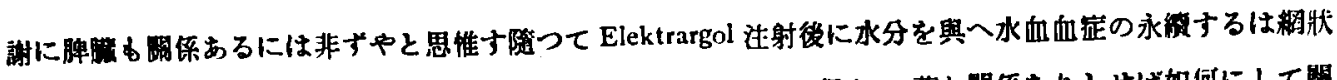

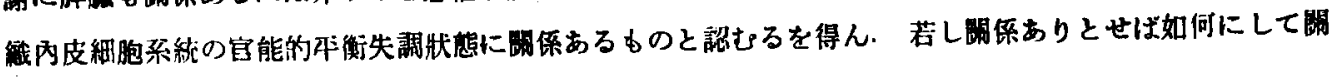
係せるかは今後の研觉に矣つて報告する所あらん・（自抄）

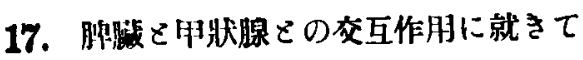

$$
\text { 柿沼內科数室 絃 島 我人君 }
$$

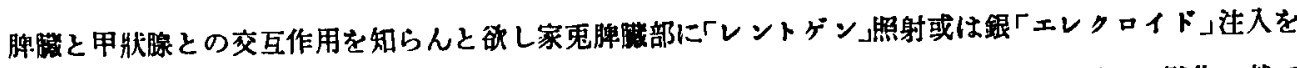

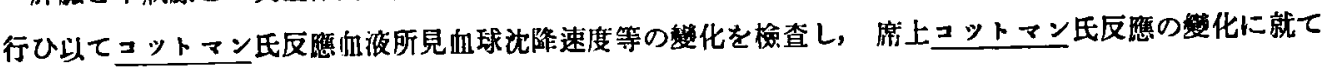
演詪せり .

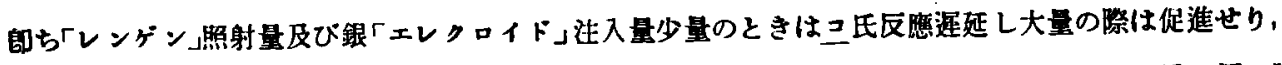

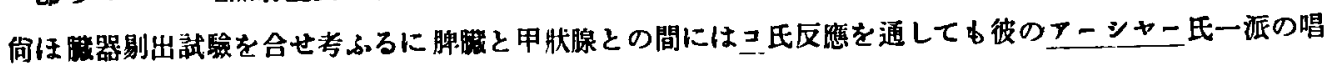
ふろが如き或種の交互作用あるを思はしむと，結諭せり（自抄）

18.「ビッグランドール」と血壓

$$
\text { 柿沼內科票空 小津倘君 }
$$

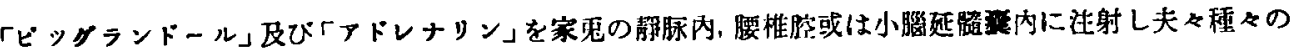

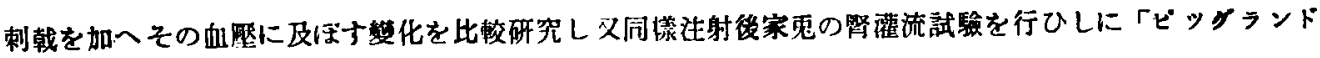
ール」は直接に血管運動神經中樞に働きてその興柏性を高むるものの如し.（自抄）

追 加

\title{
黑 瀨蝗津
}

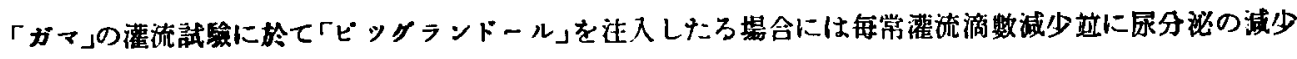
を來せり

答 辯

小津倘君

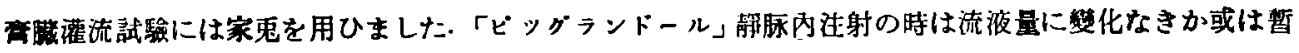

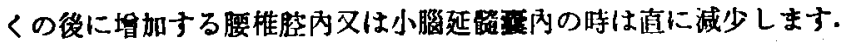

19. 組織透過性に關する䐝䁩

柿沼队科植杪 皆 雄君

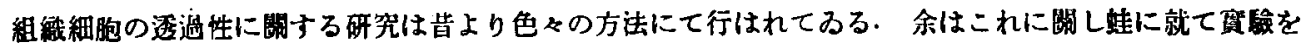

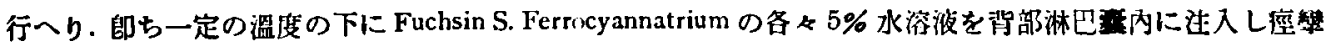

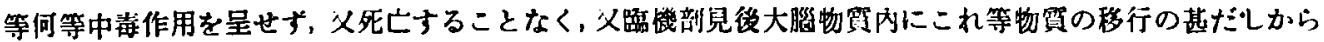
ざることを證明したる後次に $5 \%$ Diuretin, $2.5 \%$ Thenphyllinum-natr. acetic, $5 \%$ Chloral-hydrat の各水溶液 Insulin, Aetherを注入したる後に且兩侧督剔出後に前述 Fuchsin S 及び Ferrrcyan natrium 液过入をなし浐

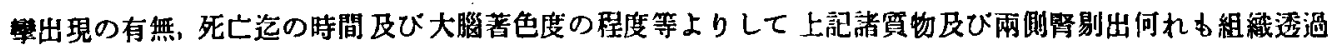

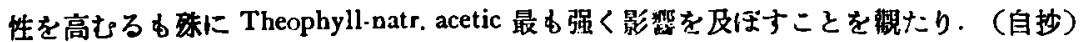
20. 溶血を脆计分泌 柿沼內科 禁告喜㔛君

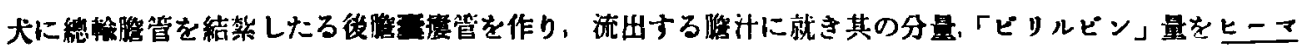




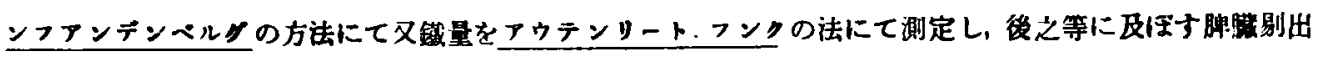

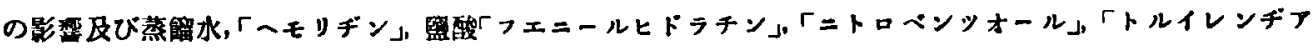

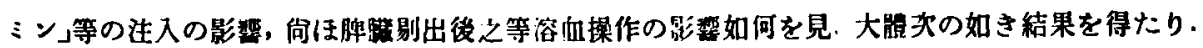

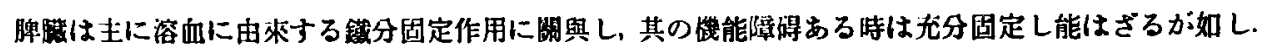

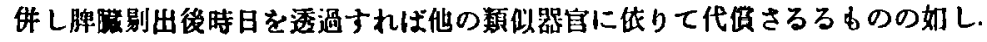

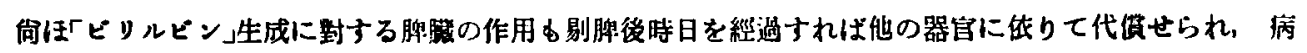
的時には網狀內被細胞織にて行はろ.

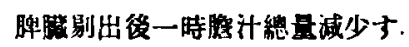

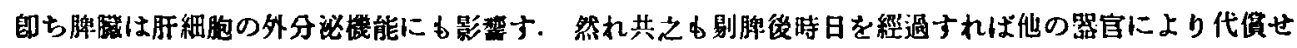
られて常態に復ナを見たり。（自抄）

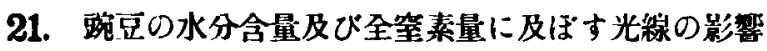

$$
\text { 生理學教室森川 份 }
$$

太陽光線の「エネルキー」が植物の新陳代謝機能に及ぼナ影嵒は日落に逳つ植物と日光の直射を受ける植 物とを比較すれば大體之を認むることを得.

かかる現象により生沼致骎指導の下に䨢险せり。

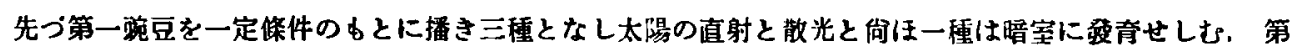

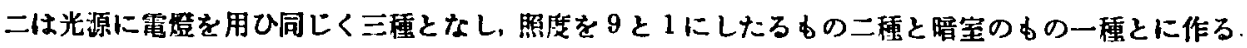

かくして出來たる六厓の「フレハラート」百六十三本に付きて检せり，その結果は次の如し.

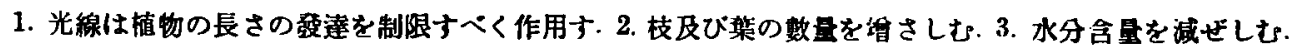

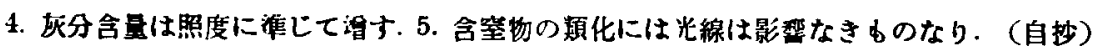
22. 海螢の發光
杽山美香霖君

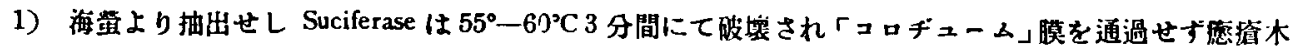

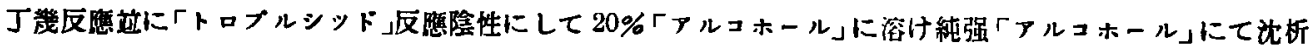
广.

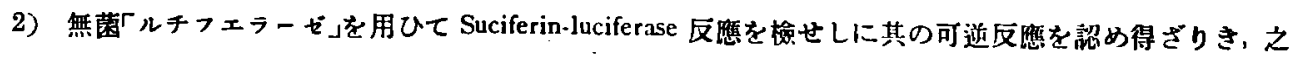

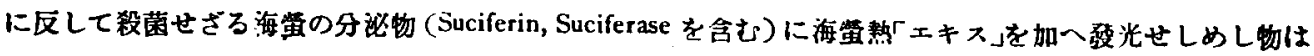
其の消光後と雖も酸素の追加により反的に磷光せしめ得たり.

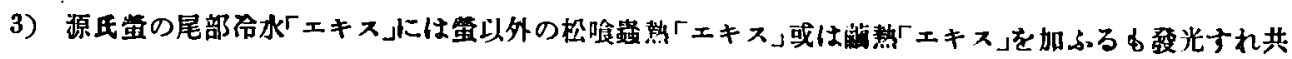

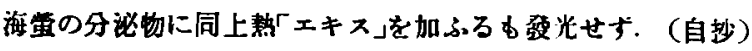

23. 心玨筋肉の最大働作

堷田宗義君

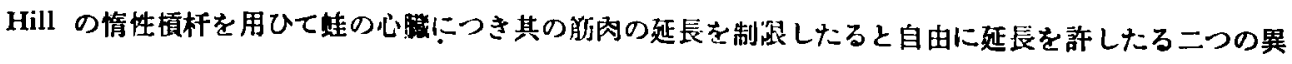

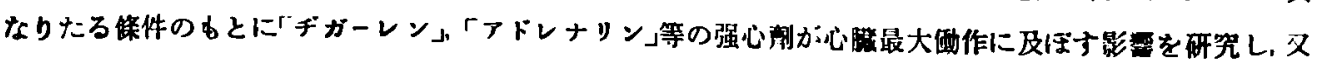

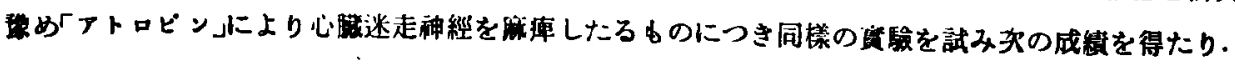




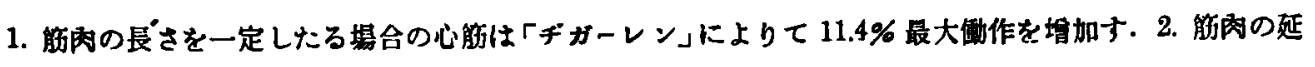

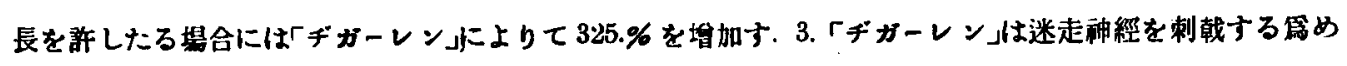

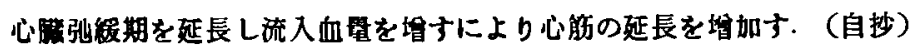

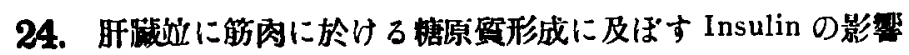

$$
\text { 大 谷 顯三君 }
$$

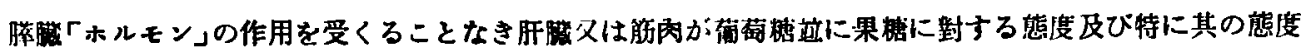

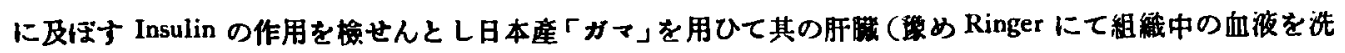

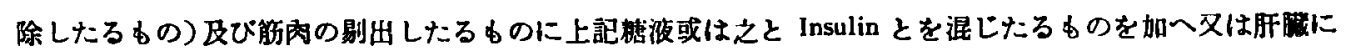

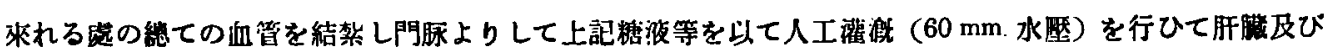

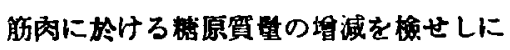

1）剔出したる肝瞵及び觔肉に於ては Insulin を加ふっことにより糖原賀は減少与。

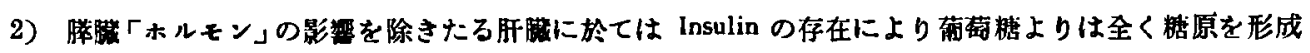
する作用を有せざるす果貄よりは之を形成する作用を有す然れどす此の作用はInsulin の存在に上りて减少 ナ.（自抄）

遍 加

佐野進君

含水炭素新陳代謝に於ける脂肪組織の形態學的研究に際し「インスリン」が如何なる程度に脂肪組緎に影

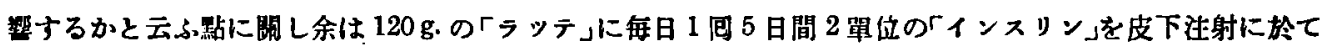

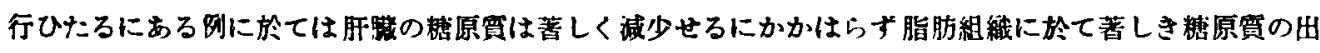

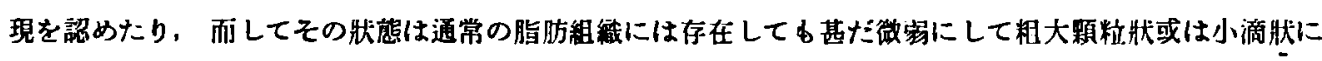

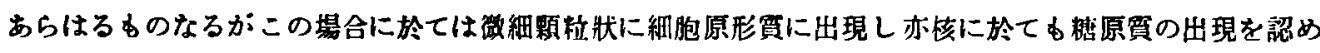
たり.（自抄）

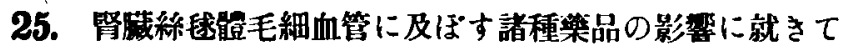

\section{岡田正矩君}

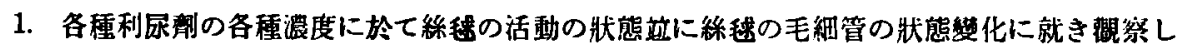

「カフメイン」は 0.2\%以上にて「安那加」は同\%にて絲建の毛細管を接張せしむ.

「ヂゥレチン」は $0.1 \%$ 以上にて同檬の反應を呈し「尿素」は $0.3 \%$ 以上にて僅に上退の作用を認むるす大 した作用を有せす。

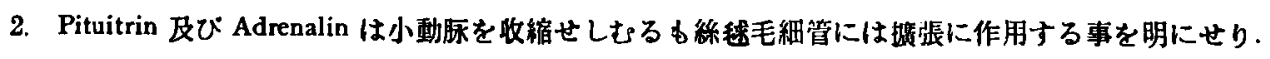

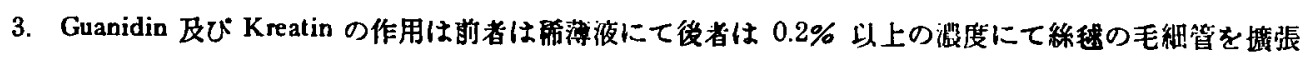
せしむ.

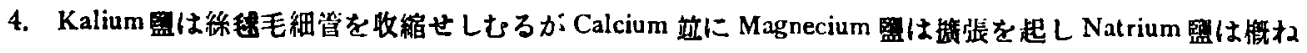

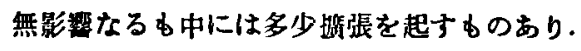

5. 有機酸は棌㲧毛細管を㩲㲀せしむ.（自抄）

右終りて書食の雼め休憩 
午後一時より再び講演を開始す

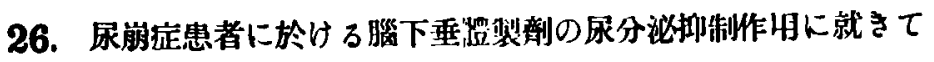

1.「ピッイトリン」の「ガマ」の血管に及ぼす影豐

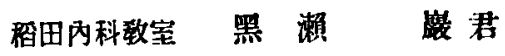

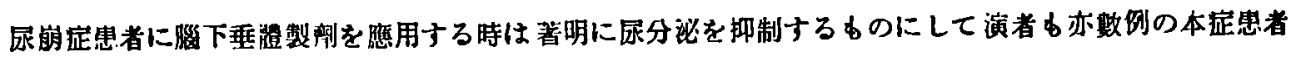

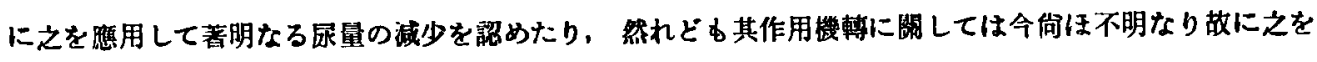

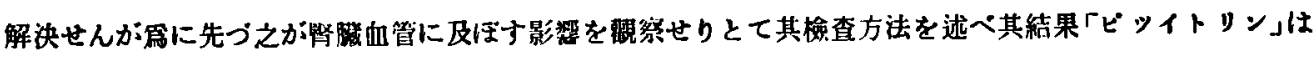

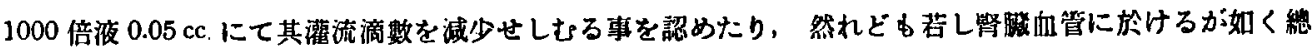

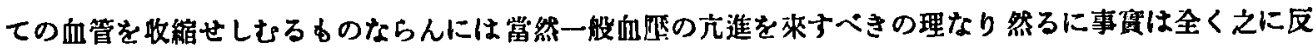

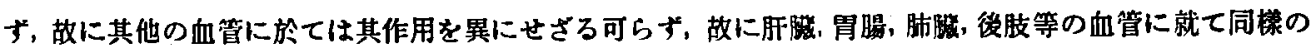

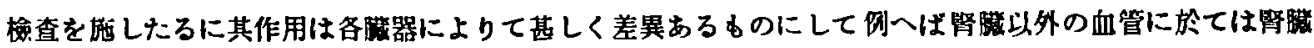

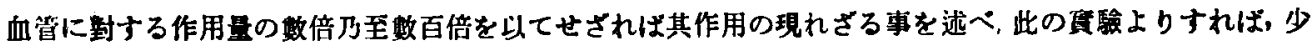

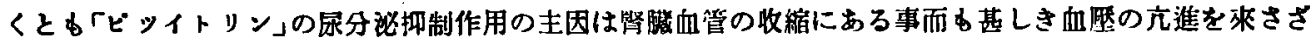
る理由は噂器によりて其作用を異にするが第なる事を述べたり。（自抄）

27. 雨腎機能の比较砛究に就きて

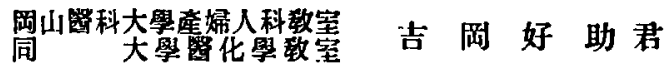

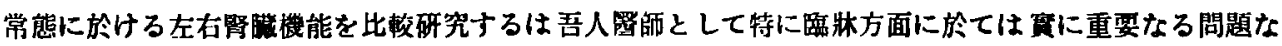
り. 1853 年以來 Goll, Ludwig, Albarran, Capsamnur, Borringer 等によりて研究せられしす同氏等の探尿方

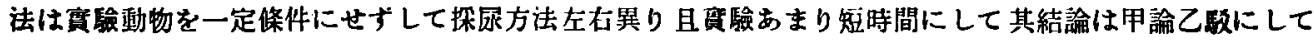

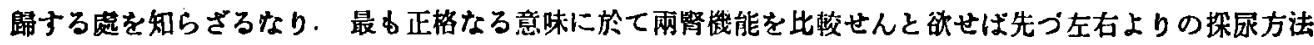

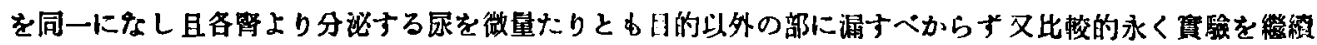
せんそせば尿傳染をむ防筧せざるべからす。

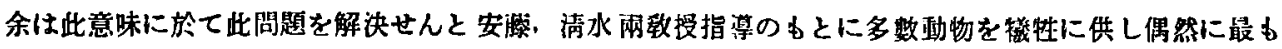
理想的なる探尿方法を考按し网腎機能を比較研究せり，余の術式は1.海備手術. 2. 探尿法の二段よりな

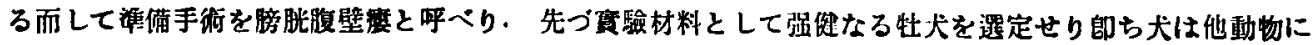

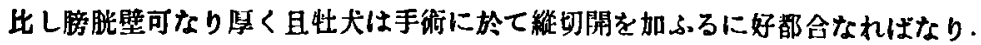

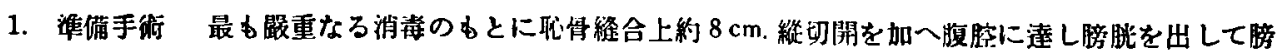

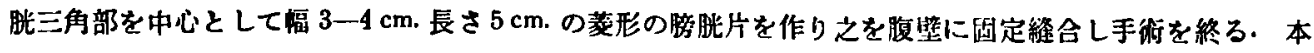

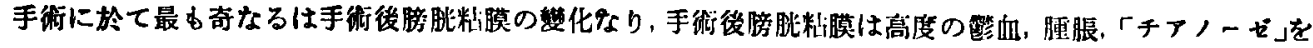

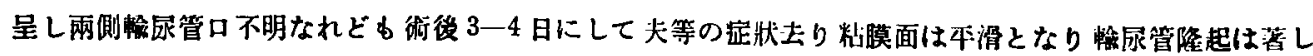
く突出し一見其所在明䭗となるあのなり．

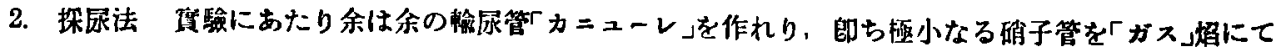

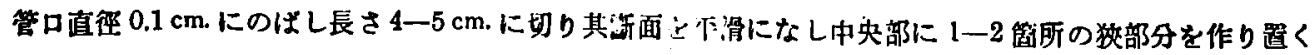

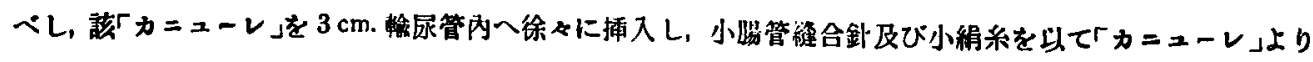




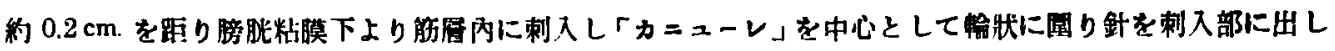
（門の口をしめる如く）堅く結禁するときは「カニューレ」は完全に圆定せられ尿は少しす漏るなく目的部に 深沓儿得.

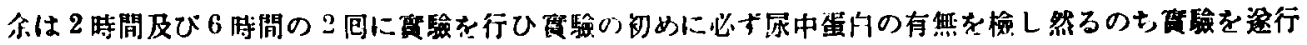
せり.

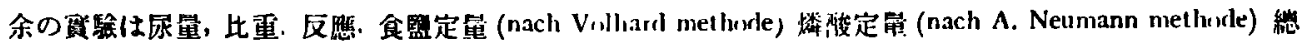

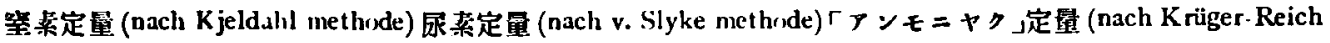
methode) 色素排湛試駼 (a. Indigokarmin. b. Phenolsulphonephthalein) 及び最後に余の左右賽驗腎の健否を知

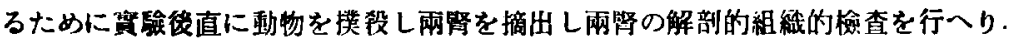

余は以上の貫臨より狄の結論を下せり.

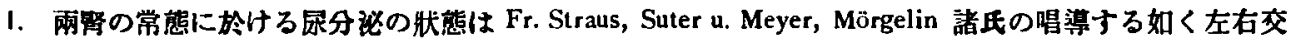
互的にして且點谪狀なり。

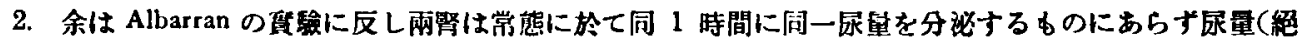
對㢆)の差異は其探尿時間に比例与。

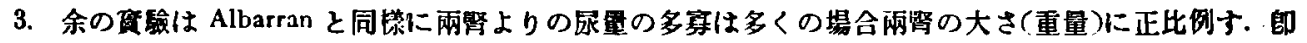
七左靔尿量は右督より大なり。

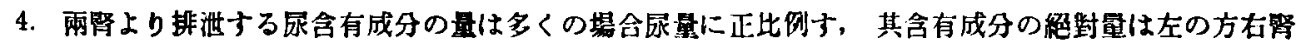
より遥に大なり.

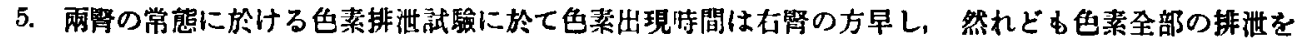
終るは左腎の方早し.

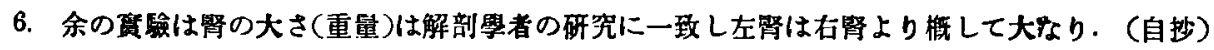

28. 掔脿の血管速動神經に就きて

\section{生理學教室 西 丸 和 義 君}

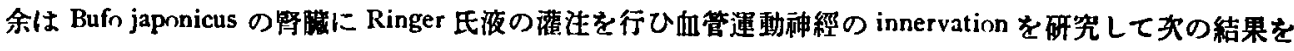
得たり.

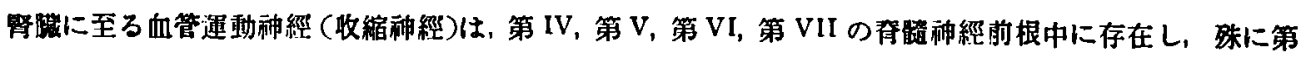
VI春路神經中には多く存在子（自技)

29. 植物性神經と白血球との涧倸に就ての呼究

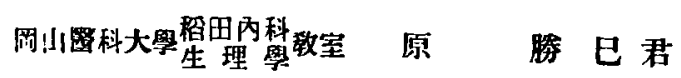

大正 12 年以來检絜しつつある Widal 氏肺機能检查法の本態に㽗与る研究の第 3 回報告にして, 今回は植

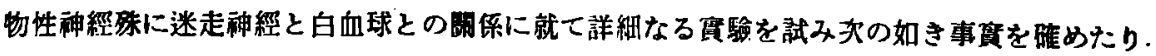

即ち迷走神經の刺戟に因り末盆血管に白血球減少を來し得へく，其の主因は從來稃へられたるが如き造

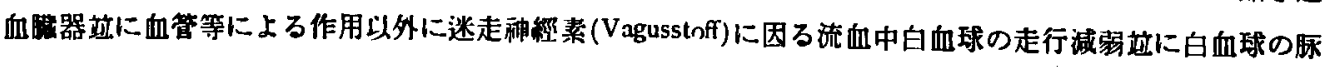
管壁集着現像等によるものなり（自抄) 


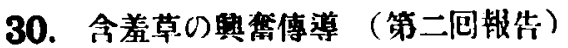

告照曹六君

奥山美传雄君

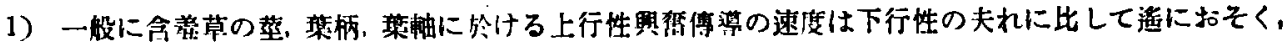

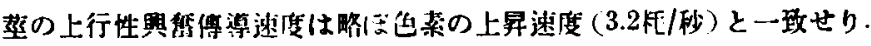

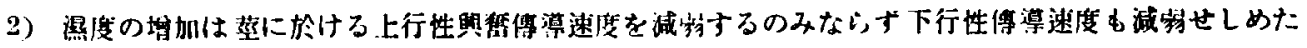

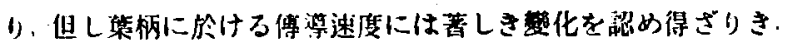

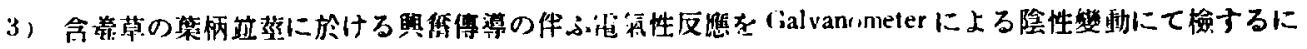
明かに二相性にして兩偝導子間を给却入は切断する事によりて一相性となし得たり。

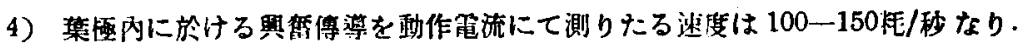

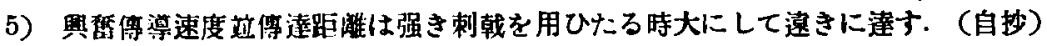

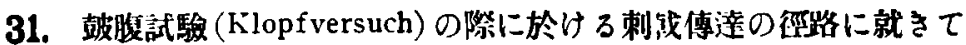

小梮交哉君

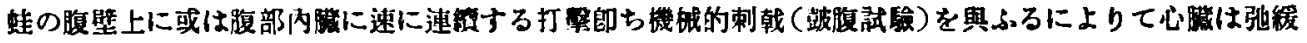
期の狀態にて䢂止す此際に於ける刺戟傅達の徑路に就て研究せり其結果次の結論を得たり・

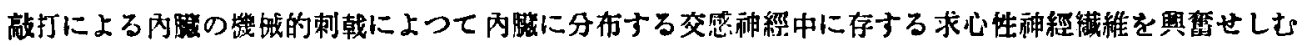

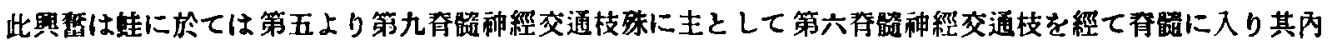

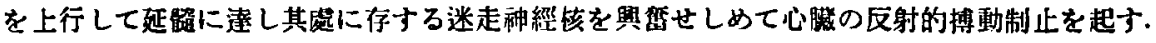

雪第的刺戟は此心射的抑制を起すに適當なる刺戟ならす。

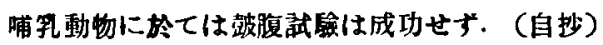

32. 迷走神經素の㤡㠰

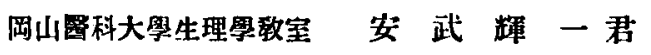

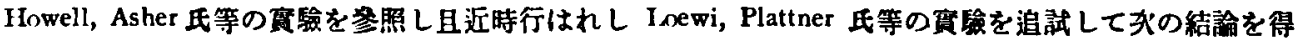
たり

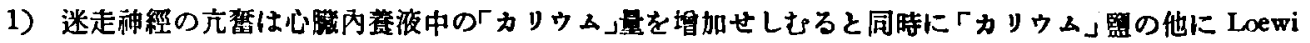

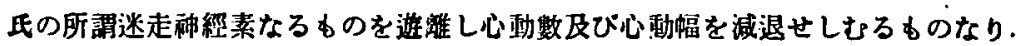

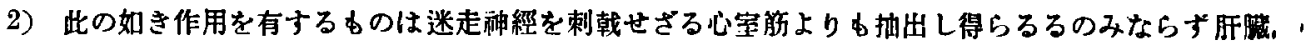
胃等よりむ抽出し得, 只其量は迷走稕經刺戟時に抽出せるすの最も多し.

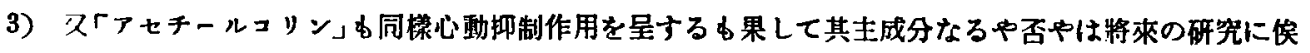
たざるべがす，（自抄）

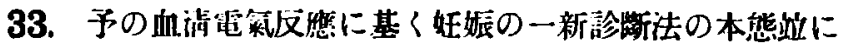
其の貨驗的研究に就きて 熊谷藏之允君

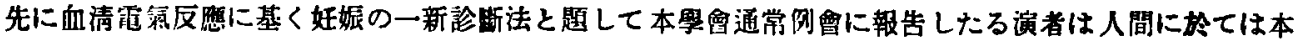
反應が果して受胎後何時より始まるかを知るに困難なると同一人に就いて度に探血すること困難にて從つ

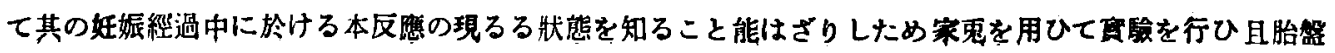




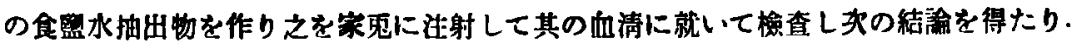

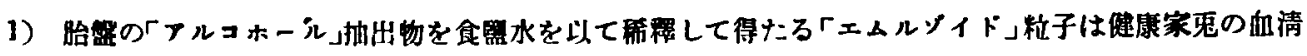

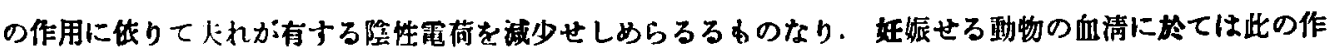
用一居等明に現るるるのなり。

2) 此の反應は家鬼に於ては早きいのは交尾後 36 時間皆通交尾後 48 時間前後より现はれ交尾後 7 日月

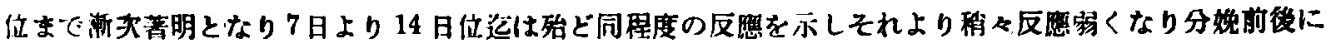

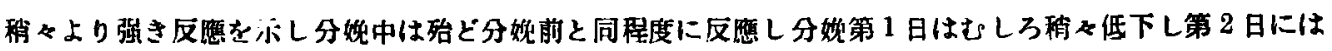

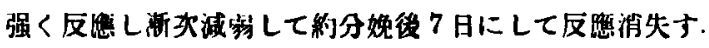

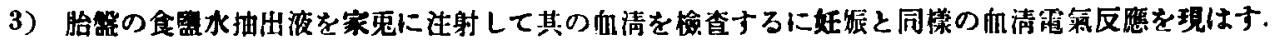

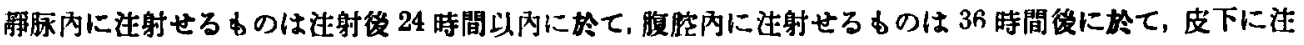

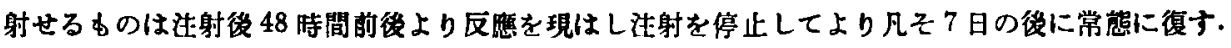

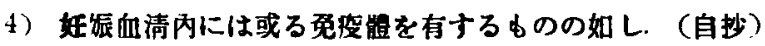

34. 所謂「ザウレ・ケルネ」の本態に就きて（第一包報告）

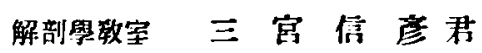

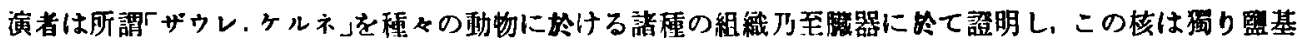

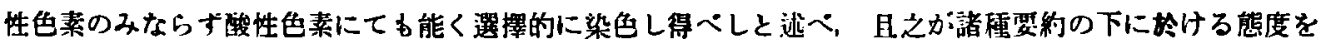

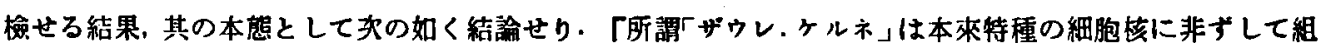

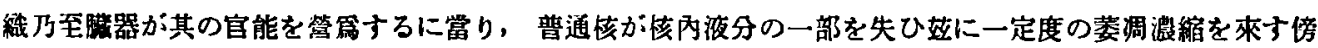

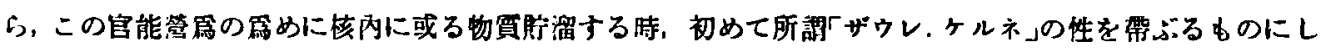

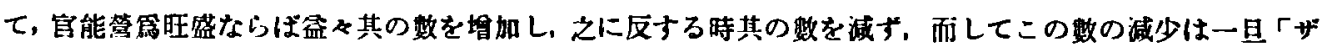

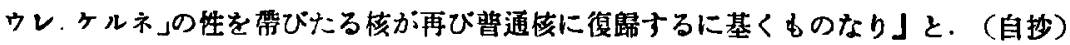

35.「グリコゲーン」染色に就きて

1. 動物性色素特に「カルネン」を以てする「グリコダーン」 染色法に就き 結 緣 主計君

演者は「クリコゲーン」の組緎學的檢秄に最す重要なる Best 氏「カルミン」染色法の染色機轉を探笢し得

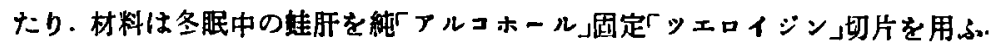

演者はBest 氏液中に全く含まれ居らざる Karmin $+\mathrm{ClH}+\mathrm{HOK}$ 但し ClH は純なるものを HOK は Normallösung を用ひ色謂の少し黑紫色となる位迄苛性加里液を加へて染色し良好なる染色標本を得たり. 又透明乘はBest 氏の云ふが如き「フルコホール」溶液の外に1-10\%の無機酸，20\%の有機酸，20\% 內外の 食學水を㮣用し得ることを知り得たり。

Best 氏法其他上述せし方法にても染色後水洗せば染色し得す，一度透明菜中に入れ後に水洗せば影䇺を

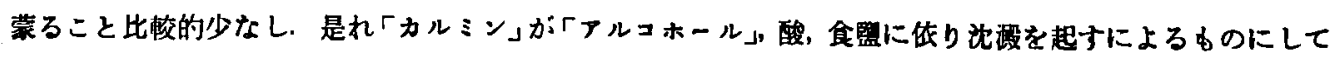

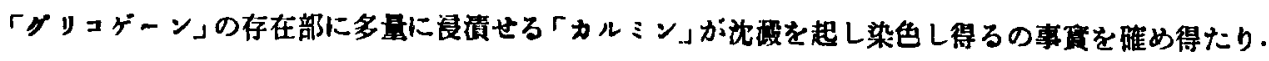




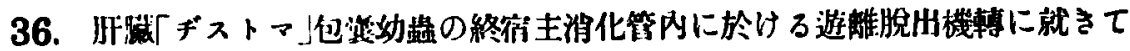

長 野寞 治君

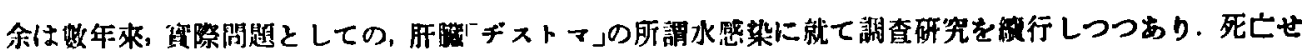

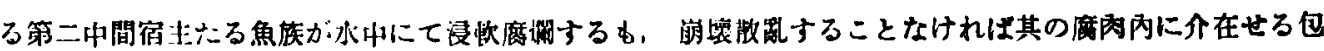

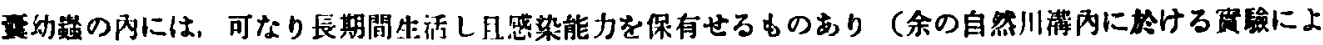

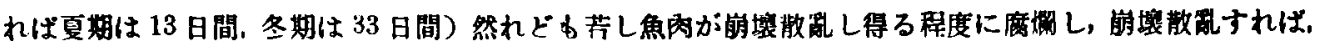

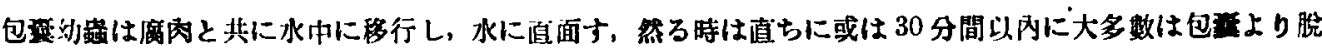

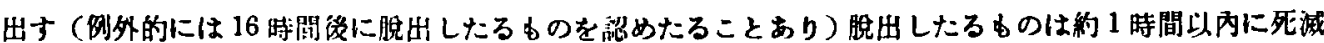

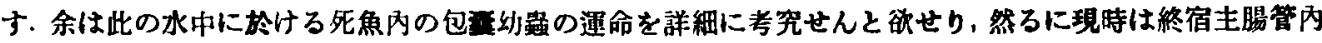

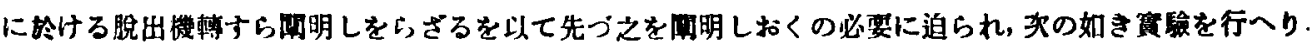

動物䆩驗: 一

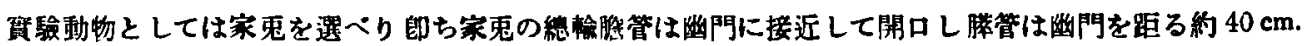

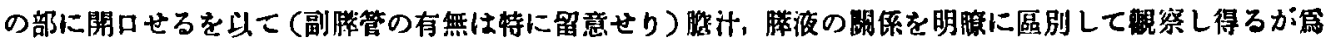

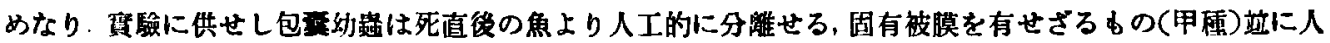

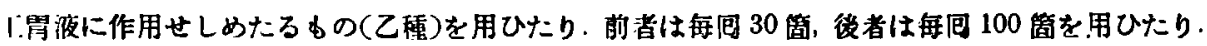

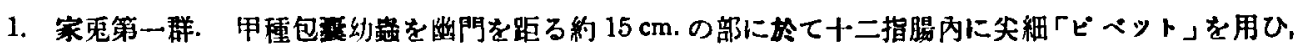

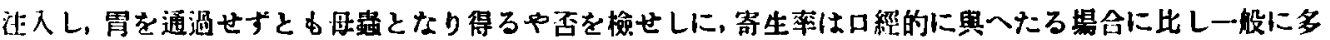

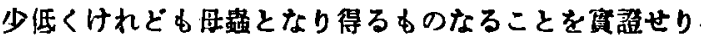

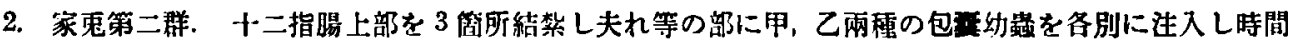
的に觀察せり.

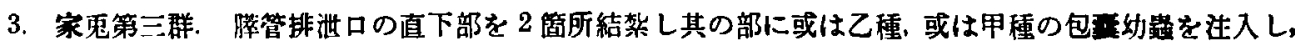
時間的に奮祭せり。

兩種共に大多數は 30 分以內に脫出与，脫出に雬寸る時間は家鬼第二群に比すれば遥に短し．消化時と否 とにより痋速あるは勿淪のことなり．

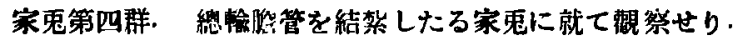

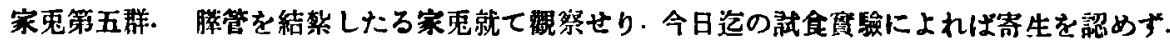

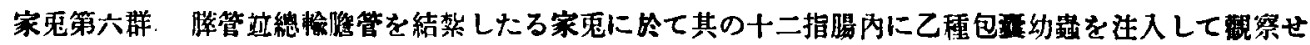
b.

試驗管內の真憸：一

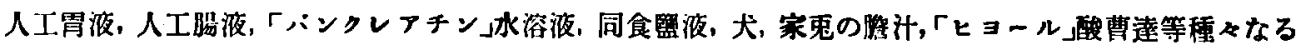

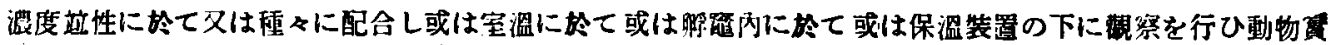
龭と全然相一玫するの結果を得たり。

結論 : -

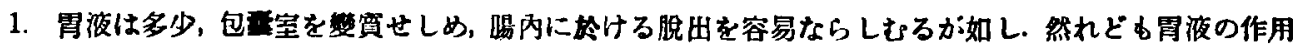
は絕對的に必要なるあのにあらず。 


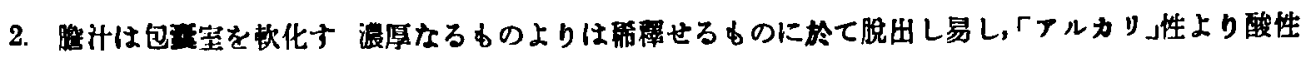

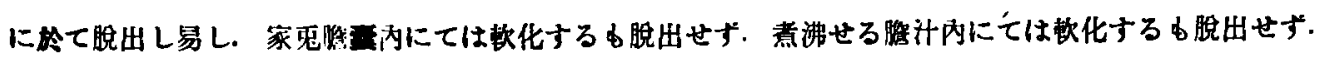

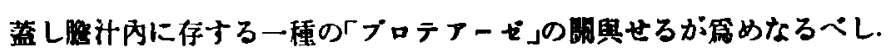

3.「ハンンンフチン」溶液は迅速且强力に包西空を軟化す, 其の量多き程作用强し. $0.3 \%$ にて 15 分間後

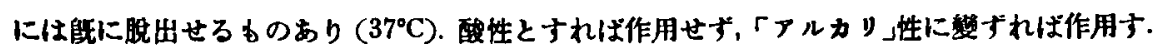

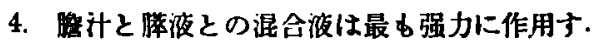

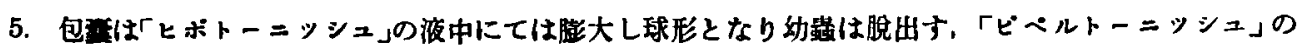

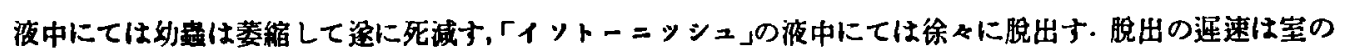
紧化に關すること勿論なり.

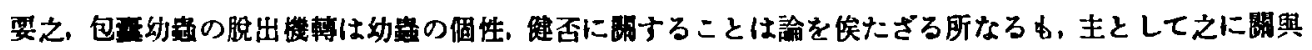

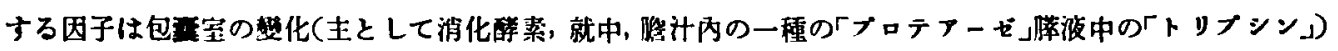

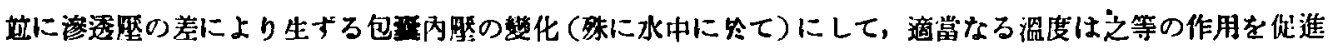
ナると同時に奻活力を與へ，脫出を容易迅速ならしむるすのなるべし.

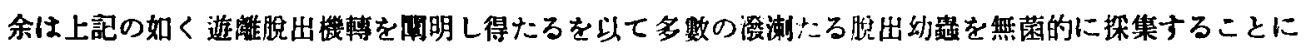

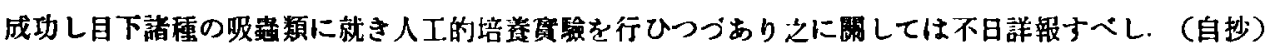

37. 鲇を中間宿主とする一新吸题類に就きた

長谷川恒治君

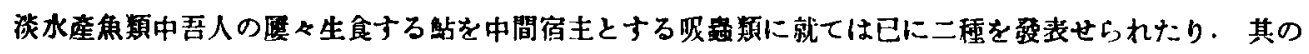
一は横川氏「メタゴニムス」にして，其の二は田部氏の「ェキノカスムス.ヤボニっス」なり．其の他に余が

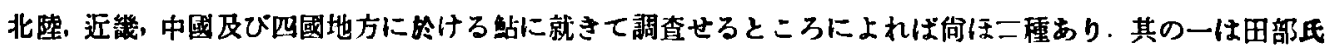

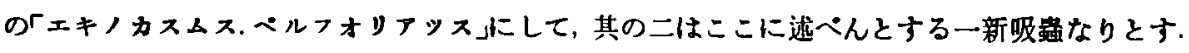

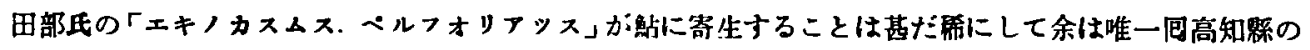

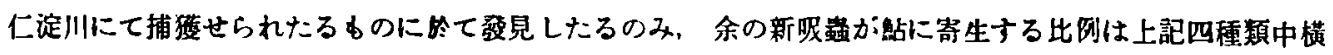
川氐「タゴニムス」に次で多きるのにして兵庫綵下に於ける調查にては横川氏「メタゴニムス」の十に對し

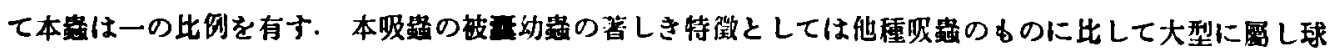

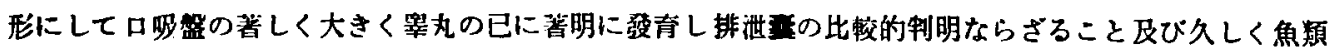

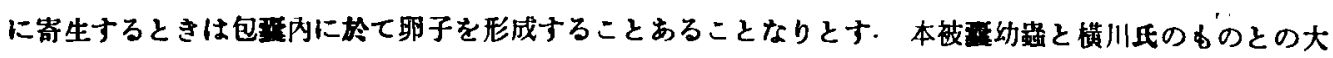

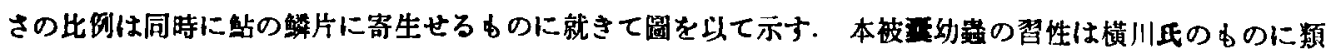

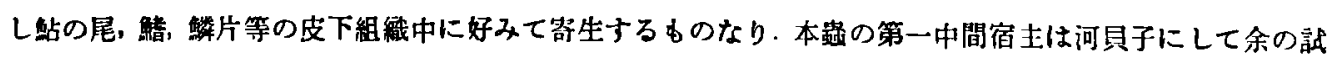

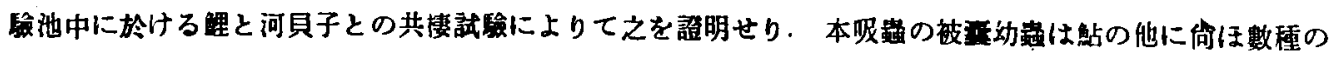
淡水産魚類を中間宿主とナ．本終宿主は绝にして其の晹管の始部に寄生し兵庫影に於ける余の調查に

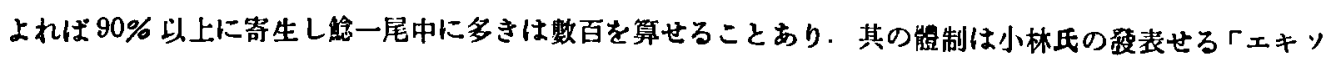

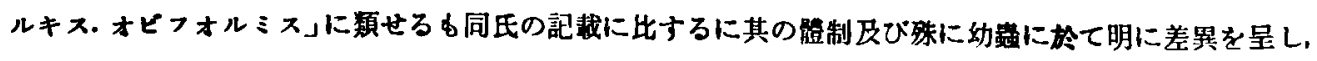

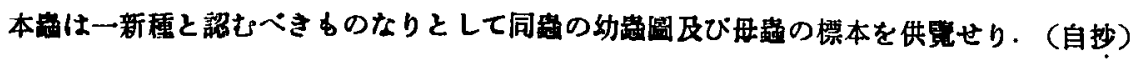

